\title{
Geçici İskemik İnmeyi Taklit Eden Nadir Bir Baş Ağrısı Nedeni Olarak HaNDL Sendromu: Olgu Sunumu
}

\author{
HaNDL Syndrome As a Rare Cause of Headache \\ Mimicking Transient Ischemic Stroke: Case Report
}

Ayşe Çağlar Sarılar' ${ }^{1}$, Murat Gültekin ${ }^{1}$, Recep Baydemir ${ }^{1}$, Mehmet Fatih Yetkin $^{1}$, Füsun Ferda Erdoğan ${ }^{1}$

${ }^{1}$ Erciyes Üniversitesi, Tıp Fakültesi, Nöroloji
$A D$, Kayseri, Türkiye

Öz

HaNDL sendromu, migren benzeri orta şiddette veya çok şiddetli baş ağrısı epizodları ile beraber geçici nörolojik defisitin görüldüğü, beyin omurilik sıvısında (BOS) lenfositoz saptanan inme ve auralı migreni taklit edebilen, nadir bir sendromdur. Tanısı, en az 4 saat süren migren benzeri baş ağrısı epizodları

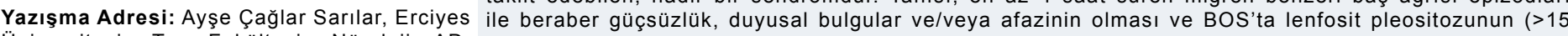

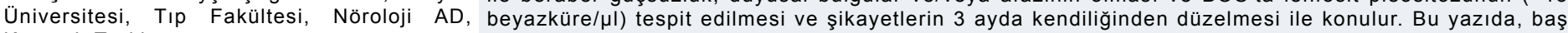
Kayseri, Türkiye

e-mail: acaglarsarikaya@gmail.com ağrısı ile beraber geçici nörolojik defisiti ve BOS'ta lenfositozu olan HaNDL sendromu tanısı konulan, kliniği takibinde tamamen düzelen 26 yaşında erkek hasta sunulmaktadır.

Geliş Tarihi/Received: 29 Mayıs 2020 Kabul Tarihi/Accepted: 15 Ekim 2020

Anahtar Kelimeler: Baş ağrısı, BOS'ta lenfositoz, geçici nörolojik defisit \begin{abstract}
HaNDL HaNDL syndrome is a rare syndrome that can mimic stroke and migraine with aura, in which migraine-like moderate or very severe headache episodes are seen together with transient neurological deficit, lymphocytosis in the cerebrospinal fluid (CSF). The diagnosis is made by the presence of migraine-like headache episodes lasting at least 4 hours, as well as weakness, sensory findings, and/or aphasia, and lymphocyte pleocytosis (>15 white blood cells $/ \mu \mathrm{l}$ ) in the CSF, and spontaneous resolution of complaints in 3 months. In this article, we present a 26 -year-old male patient who was diagnosed with HaNDL syndrome with headache, transient neurological deficit and lymphocytosis in the CSF, and completely recovered during clinical follow-up.
\end{abstract}

Key words: Headache, CSF Iymphocytosis, transient neurological deficit

Atıf yapmak için: Sarılar Çağlar A, Gültekin M, Baydemir R, Yetkin MF, Erdoğan FF. Geçici İskemik İnmeyi Taklit Eden Nadir Bir Baş Ağrısı Nedeni Olarak HaNDL Sendromu: Olgu Sunumu. Selcuk Med J 2021;(2): 172-175
Açıklama: Yazarların hiçbiri, bu makalede bahsedilen herhangi bir ürün, aygıt veya ilaç ile ilgili maddi çıkar ilişkisine sahip değildir. Araştırma, herhangi bir dış organizasyon tarafından desteklenmedi. Yazarlar çalışmanın birincil verilerine tam erişim izni vermek ve derginin talep ettiği takdirde verileri incelemesine izin vermeyi kabul etmektedirler. 


\section{GíRiş}

HaNDL sendromu ('Transient headache and neurologic deficits with cerebrospinal fluid lymphocytosis"), migren benzeri orta şiddette veya çok şiddetli baş ağrısı epizodları ile beraber geçici nörolojik defisitin görüldüğü, BOS'ta lenfositoz saptanan inme ve auralı migreni taklit edebilen, nadir bir sendromdur (1). Uluslar arası baş ağrısı bozuklukları sınıflaması3'e göre, sekonder baş ağrıları başlığı altında, 7.3.5 bendinde "İnfeksiyöz olmayan inflamatuar intrakraniyal bozukluklara bağlanan baş ağrıları" bölümünde değerlendirilmektedir. Bu sınıflamaya göre tanı ; en az 4 saat süren migren benzeri baş ağrısı epizodları ile beraber güçsüzlük, duyusal bulgular ve/ veya afazinin olması ve BOS'ta lenfosit pleositozunun (>15 beyazküre/ $\mu \mathrm{l}$ ) tespit edilmesi ve şikayetlerin 3 ayda kendiliğinden düzelmesi ile konulur (2).

HaNDL sendromu, ilk kez Bertelson et al. (3) tarafından 1981 yılında migren benzeri baş ağrısı atakları ve BOS'ta lenfositozu olan yedi vakada tanımlanmıştır. Bu zamana kadar literatürde 200'den fazla hasta bildirilmiştir (1). Tanısı, baş ağrısı ve BOS'ta lenfositoz saptandığı için hayati tehlike yaratabilecek diğer nedenleri dışlayarak konulmalıdır. HaNDL sendromu tanısı konulduktan sonra tedavisi semptomatiktir. Bu yazıda, baş ağrısı ile beraber geçici nörolojik defisiti ve BOS'ta lenfositozu olan HaNDL sendromu tanısı konulan ve semptomları kendiliğinden düzelen 26 yaşında erkek hasta sunulmaktadır.

\section{OLGU}

Yirmialtı yaşında erkek hasta, fotofobi ve fonofobinin eşlik ettiği, zonklayıcı ve temporal bölgede hakim olan ve genellikle en az 4-5 saat süren baş ağrılarının son 6 aydır ayda bir-iki kez olan baş ağrılarının son 3 haftada şiddetinin artması yakınması ile başvurdu. Daha önceleri bu ağrısı için çeşitli nonstreoidal antienflamatuar ilaçlar aldığı ancak düzenli takibinin yapılmadığı öğrenildi. Son zamanlarda olan baş ağrısına sağ vücut yarısında olan ve 30 dakika kadar sürüp geçen uyuşmanın da eklendiğini belirtti. Hastanın özgeçmişinde herhangi bir problem yoktu. Muayenesinde şiddetli baş ağrısı ile beraber sağ hemihipoestezisi mevcuttu ve ateşi yoktu. Rutin kan tetkikleri normal sınırlardaydı. Kraniyal MRG'sinde solda temporal bölgede kistik bir lezyon mevcuttu (Şekil 1). Geçici nörolojik defisitinin olması nedeniyle ve olası baş ağrısı sekonder sebepleri dışlamak için yapılan serebral ve supraaortik MR anjiografi ve MR venografi değerlendirmeleri normaldi. Çekilen
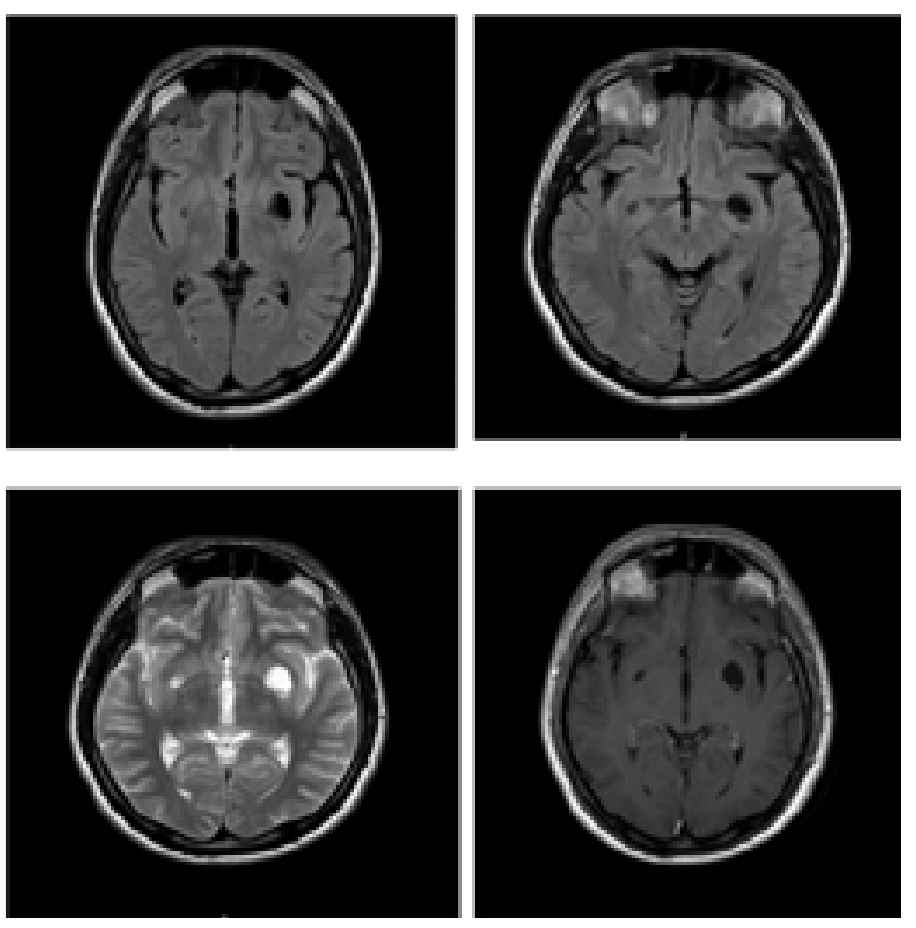

Şekil 1. Kraniyal MRG: T1 ve FLAIR görüntülerde sol temporal bölgede kistik lezyon mevcuttur

elektroensefalografisi (EEG)'de de herhangi bir problem saptanmadı. Yapılan lomber ponksiyonunda

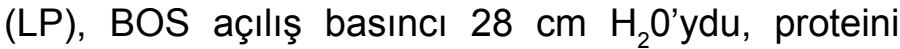
yüksekti (125 mg/dl), lenfositozu mevcuttu (12 beyazküre/ $\mu \mathrm{l})$, şekeri normal sınırlardaydı.

Hastanın BOS'ta lenfositozu olduğu için enfeksiyona yönelik ayrıntılı değerlendirme yapıldı ancak enfeksiyöz ajan bulunamadı. Tedavide aurasız tipte olan migrenine yönelik triptanlar ve parasetamol verildi ve hidrasyonu yapıldı. Hastanın takibinde, mevcut sağ hemihipoestezisinin 30 dakika kadar sürdüğü ve spontan olarak düzeldiği gözlendi. Yatışının 10. Gününde yapılan kontrol LP'sinde BOS açılış basıncı 180, BOS proteini $37.1 \mathrm{mg} / \mathrm{dl}$ ve hücresi 1 beyaz küre/ $\mu$ l olmak üzere normal sınırlarda geldi. Hastada baş ağrısı ile beraber geçici nörolojik defisitin olması ve BOS'ta lenfositozunun olması nedeni ile HaNDL sendromu tanısı konuldu. Aurasız migren vasfında baş ağrıları nedeni ile parasetamol ve triptan tedavisi düzenlerek taburcu edildi. Taburculuk sonrası kontrolünde hastanın herhangi bir problemi yoktu.

\section{TARTIŞMA}

$\mathrm{Bu}$ yazıda sunduğumuz HaNDL sendromu olgusunun doğru tanı alması üç hafta sonra olabilmiştir. 
Bu süre içinde çeşitli merkezlerde serebrovasküler olay ve diğer nedenler için tekrarlayan incelemeler yapılmış, ancak hasta doğru tanı almamıştı. Bu yüzden hasta endişeli ve anksiyöz duygulanımdaydı. Genellikle geç tanı aldığından dolayı bu hastalara gereksiz bir çok tetkik yapılmaktadır. Bu nedenle, şiddetli baş ağrısı, geçici nörolojik defisit ve BOS'ta lenfositoz varlığında diğer nedenleri ekarte edildikten sonra nöroloji baş ağrısı pratiğinde bu tür vakalar göz ardı edilmemeli ve HaNDL sendromu akla getirilmelidir.

HaNDL sendromu, 15-40 yaşları arası kişilerde daha fazla görülmektedir (4). Hastalarda migrenöz vasıfta baş ağrısı olmaktadır. Migren her ne kadar kadınlarda daha sık görülüyor olsa da HaNDL sendromu erkeklerde daha fazla gözlenmektedir. Hastalarda orta şiddette veya çok şiddetli pulsatil vasıfta baş ağrısı olmaktadır. Aynı zamanda, bulantı/ kusma, ışık-ses hassasiyeti yüksek oranda eşlik etmektedir. Baş ağrılarının \%60'ı iki taraflıdır ve ağrı süreleri ortalama 19 saat olarak bildirilmiştir (5). Erişkinlerde görülen en sık nörolojik defisit duyusal semptomlardır (6). Hastaların büyük çoğunluğunda fokal nörolojik defisitler tek hemisfere sınırlıdır. Hastaların dörtte üçünde hemiparestezi görülmekle beraber, yarısında disfazi, yarısından biraz fazlasında hemiparezi görülmektedir ki bunlar genellikle nörolojik sekel bırakmadan iyileşirler (7). Gözlenebilecek diğer nörolojik defisitlerin arasında vizüel semptomlar (görme azalması, homonim hemianopi, fotopsiler, papilödem, 6.sinir palsisi) olabilmektedir (8). Nadir olarak konfüzyon tablosu da gelişebilmektedir (9). Geçici nörolojik defisitlerin ortalama süresi 5 saat olarak bildirilmiştir (6). Hastaların BOS'larında mutlaka lenfositoz olmalıdır ve bildirilen ortalama lenfosit sayısı $199 \pm$ 174/mm3'dür. Hastaların \%96'sında BOS proteininin ve \%56'sında BOS açılış basıncının yükseldiği bildirilmiştir (6). Hastaların EEG'lerinde geçici fokal ve epileptik olmayan değişiklikler de saptanabilir(10).

Hastalığın kesin etyolojisi bilinmemekle beraber bu konuda oldukça fazla değişik görüşler bulunmaktadır. Bazı hastaların baş ağrılarının, nörolojik defisit olan tarafın kontrlateralinde daha fazla şiddette olduğunu belirtmeleri, gerçek bir vasküler orijin veya dolaylı olarak arteryel değişikliklere neden olan enflamatuar bir sürece kanıt olarak düşünülmektedir (8). Hastaların bir çoğunda semptomlar başlamadan önce prodromal viral hastalık dönemi tarif etmelerinden ötürü hastalığın patogenezinde enfeksiyöz ya da enflamatuar bir tetikleyici süreç olduğu düşünülmektedir. Bununla beraber, kapsamlı bir viral serolojik değerlendirme yapılmasına rağmen viral etyolojiyi kanıtlayabilen çok nadir çalışma bulunmaktadır (11-13). Bu durumda da, viral enfeksiyonun immün sistemi tetikleyip nöronal antikorları üretmesi veya vasküler antijenlerin aseptik leptomeningeal vaskülite neden olabilmesi ve bu durumun semptomlara yol açması fikri ön plana çıkmıştır (4). İnflamatuar veya otoimmün patogeneze destek olabilecek diğer çalışmalarda ise; HaNDL sendromu olgularında DNA tamir proteinlerine karşı antikorlar ve T-tipi voltaj kapılı kalsiyum kanallarının CACNA1H subünitine karşı antikorlar geliştiği gösterilmiştir $(14,15)$.

HaNDL sendromunda kraniyal MRG'lerin genel olarak normal olması beklenmektedir ancak kraniyal MRG'de nörolojik defisitin olduğu dönemde ve nörolojik defisitin kontrlateralindeki hemisferde gri maddede ödemin gösterildiği olgu da bildirilmiştir (16). Bununla beraber gadolinyumla çekilen kraniyal MRG'de leptomeningeal kontrast tutulumu da olabileceği gösterilmiştir (1). Konvansiyonel kraniyal anjiografinin de normal olması beklenmektedir (6). Perfüzyon görüntülemelerde hipoperfüzyon olduğu gösterilmiştir ve kontrol BT perfüzyon çekilen hastada hipoperfüzyonun düzeldiğinin gösterilmesi kortikal yayılan depresyon mekanizmasının patogenezde rol aldığını düşündürmektedir (17). HaNDL sendromu hastalarında yapılan SPECT görüntülemelerinde akut fazda nörolojik defisitle uyumlu olan taraftaki kortikal bölgede radyonüklid alımında azalma ve fokal hipoperfüzyon olduğu da gösterilmiştir (18). Transkraniyal Doppler (TKD) ile a.serebri media'da asimetrik akım ve pulsatiliteler tespit edilebilir ve bu durum da hastalığın patofizyolojisinde intrakraniyal vazomotor değişikliklerin rol oynadığı fikrini desteklemektedir (19). Hastalarda yapılan elektrofizyolojik incelemelerde (tek lif EMG, görsel ve işitsel uyarılmış potansiyeller, sinir iletim çalışması) sonuçları auralı migren hastalarındaki sonuçlar ile benzer olarak bulunmuştur (20).

Hastalığın semptomlarının familyal hemiplejik migrenle(FHM) benzer olması olası ortak genetik veya metabolik (kanalopati?) mekanizmaları düşündürmektedir. Her iki durumda da geçici olan motor ve duyusal defisitler olup, bazen vizüel aura da eşlik edebilmektedir. FHM vakalarının \%50'sinde 19. kromozomda bulunan $P / Q$ tipi kalsiyum kanal geninin a1a subünitiyle genetik bağlantı tespit edilmiştir. Bu durumda CACNA1a gen mutasyonunda veya polimorfizminde HaNDL sendromuna yatkınlık olabileceği hipotezi öne sürülmüştür ancak bu hipotez 
henüz kanıtlanamamıştır(15).

Sonuç olarak; baş ağrısı ile beraber geçici nörolojik defisiti ve BOS'ta lenfositozu olan hastalarda, diğer tüm nedenler dışlandıktan sonra HaNDL sendromu olasılığı akılda tutulmalıdır. Hastalığın tanısı konulduktan sonra semptomların çoğunlukla spontan olarak düzelmesi nedeni ile tedavisinde semptomatik yaklaşmanın uygun olduğu düşülmektedir.

Çıkar Çatışması: Çalışmada herhangi bir çıkar çatışması yoktur.

Finansal Çıkar Çatışması: Çalışmada herhangi bir finansal çıkar çatışması yoktur.

Yazışma Adresi: Ayşe Çağlar Sarılar, Erciyes Üniversitesi, Tıp Fakültesi, Nöroloji AD, Kayseri, Türkiye

Telefon: 05055716835

e-mail: acaglarsarikaya@gmail.com

\section{KAYNAKLAR}

1. Armstrong-Javors A, Krishnamoorthy K. HaNDL syndrome: Case report and literature review. J Child Neur 2019;34(3):161-7.

2. Society $\mathrm{HCCotIH}$. The international classification of headache disorders, (beta version). Cephalalgia 2013;33(9):629-808.

3. Bartleson JD, Swanson JW, Whisnant JP. A migrainous syndrome with cerebrospinal fluid pleocytosis. Neurology 1981;31(10):1257-.

4. Pascual J, Valle N. Pseudomigraine with lymphocytic pleocytosis. Cur Pain Headache Rep 2003;7(3):224.

5. Tada Y, Negoro K, Abe M, et al. A patient of migrainelike headache with amnesia, pleocytosis and transient hypoperfusion of cerebral blood flow. Int Med 2005;44(7):7436.

6. Gómez-Aranda F, Canadillas F, Martí-Massó J, et al. Pseudomigraine with temporary neurological symptoms and lymphocytic pleocytosis. A report of 50 cases. Brain 1997;120(7):1105-13.

7. Rivero-Sanz E, Pias-Peleteiro L, Gonzalez-Alvarez V. HaNDL syndrome in a 14-year-old girl. Case Rep 2016;2016:bcr2015213018.

8. Valença MM, de Oliveira DA, Martins HAdL. Alice in Wonderland syndrome, burning mouth syndrome, cold stimulus headache, and HaNDL: Narrative review. Headache: J Head Face Pain 2015;55(9):1233-48.

9. Türkan A, Bilgehan Atılgan A, Karabacak MYGA. Konfüzyon ile prezente olan HaNDL sendromu: Nadir bir olgu sunumu. Arch Neuropsychiatry 2020;57:340-2.

10. Doğan EA, Güney FB, Emine $G$, et al. Geçici nörolojik bulgular, başağrısı ve bos lenfositozu-HaNDL sendromu. Selçuk Tıp Derg 2008;24:227-229.

11. Emond $H$, Schnorf $H$, Poloni $C$, et al. Syndrome of transient headache and neurological deficits with CSF lymphocytosis (HaNDL) associated with recent human herpesvirus-6 infection. Cephalalgia 2009;29(4):487-91.

12. Stelten BM, Venhovens J, van der Velden LB, et al. Syndrome of transient headache and neurological deficits with cerebrospinal fluid lymphocytosis (HaNDL): A case report with serial electroencephalography (EEG) recordings.
Is there an association with human herpes virus type 7 (HHV7) infection? Cephalalgia 2016;36(13):1296-301.

13. Vieira JP, Brito MJ, de Carvalho IL. Borrelia lusitaniae infection mimicking headache, neurologic deficits, and cerebrospinal fluid lymphocytosis. J Child Neur 2019;34(12):748-50.

14. Erdağ E, Çelebisoy N, Yüceyar AN, et al. Antibodies to DNA repair proteins in headache with neurological deficits and cerebrospinal fluid lymphocytosis (HaNDL) patients. Act Neur Belgica 2015;115(2):137-40.

15. Chapman KM, Szczygielski BI, Toth $\mathrm{C}$, et al. Pseudomigraine with lymphocytic pleocytosis: A calcium channelopathy? Clinical description of 10 cases and genetic analysis of the familial hemiplegic migraine gene CACNA1A. Headache 2003;43(8):892-5.

16. Yilmaz A, Kaleagasi $H$, Dogu $O$, et al. Abnormal MRI in a patient with 'headache with neurological deficits and CSF lymphocytosis (HaNDL)'. Cephalalgia 2010;30(5):615-9.

17. Burke $M$, Lamb $M$, Hohol $M$, et al. Unique CT Perfusion Imaging in a Case of HaNDL: New insight into pathophysiology of acute attacks. Cephalalgia 2017;57(1):129-34.

18. Fuentes B, Diez Tejedor E, Frank A. Syndrome of headache with neurological deficits and CSF lymphocytosis: Aspreading depression mechanism? The role of SPECT. Headache 1998;38(4):324.

19. KapplerJ,MohrS,SteinmetzH.Cerebralvasomotorchanges in the transient syndrome of headache with neurologic deficits and CSF lymphocytosis (HaNDL). Headache 1997;37(8):5168.

20. Fumal A, Vandenheede M, Coppola G, et al. The syndrome of transient headache with neurological deficits and CSF lymphocytosis (HaNDL): Electrophysiological findings suggesting a migrainous pathophysiology. Cephalalgia 2005;25(9):754-8. 